\title{
Analisis Kemampuan Penalaran Deduktif Matematis Siswa
}

\author{
Ahmad Fadillah \\ Program Studi Pendidikan Matematika, Universitas Muhammadiyah Tangerang, Indonesia \\ ahmadfadillah@umt.ac.id
}

\section{INFO ARTIKEL}

Riwayat Artikel:

Diterima: 27-02-2019

Disetujui: 20-04-2019

\section{Kata Kunci: \\ Penalaran; Deduktif; Matematis}

\section{ABSTRAK}

Abstrak:Tujuan penelitian ini adalah untuk mengetahui kemampuan penalaran deduktif matematis siswa dalam menyelesaikan soal matematika bentuk cerita pokok bahasan aplikasi turunan. Penelitian ini dilakukan di SMA Muhammadiyah 02 Cipondoh Tangerang. Pengumpulan data dilakukan dengan metode observasi, wawancara, tes dan studi dokumentasi. Teknik analisis data menggunakan analisis data kualitatif yang meliputi reduksi data, penyajian data dan menarik kesimpulan/verifikasi. Berdasarkan hasil penelitian diperoleh siswa dengan kemampuan penalaran deduktif tinggi mencapai $12,82 \%$, siswa dengan kemampuan penalaran deduktif sedang mencapai $71,8 \%$ dan siswa dengan kemampuan penalaran deduktif rendah mencapai $15,38 \%$.
\end{abstract}

\section{Key Words:}

Reasoning; Deductive; Mathematic.

\begin{abstract}
The purpose of this research is to know the mathematical deductive reasoning ability of students in solving math story form the subject of derivative applications. This research was conducted in High School of Muhammadiyah 02 Cipondoh Tangerang. Data collection is done by the method of observation, interview, test and study of documentation. Data analysis techniques used qualitative data analysis that included the reduction of the data, the presentation of the data and draw conclusion/verification. Based on the research results obtained by students with high ability of deductive reasoning reached $12.82 \%$, students with middle ability of deductive reasoning reached $71.8 \%$ and students with low ability deductive reasoning reached $15.38 \%$.
\end{abstract}

\section{do: 3 Crossref}

This is an open access article under the CC-BY-SA license

\section{A. LATAR BELAKANG}

Permendiknas Nomor 22 Tahun 2006 tentang Standar Isi Mata Pelajaran Matematika, tujuan pembelajaran matematika adalah agar siswa mampu: (1) Memahami konsep matematika, menjelaskan keterkaitan antarkonsep dan mengaplikasikan konsep atau algoritma, secara luwes, akurat, efisien, dan tepat, dalam pemecahan masalah, (2) Menggunakan penalaran pada pola dan sifat, melakukan manipulasi matematika dalam membuat generalisasi, menyusun bukti, atau menjelaskan gagasan dan pernyataan matematika, Memecahkan masalah yang meliputi kemampuan memahami masalah, merancang model matematika, menyelesaikan model dan menafsirkan solusi yang diperoleh, (4) Mengomunikasikan gagasan dengan simbol, tabel, diagram, atau media lain untuk memperjelas keadaan atau masalah, dan (5) Memiliki sikap menghargai kegunaan matematika dalam kehidupan, yaitu memiliki rasa ingin tahu, perhatian, dan minat dalam mempelajari matematika, serta sikap ulet dan percaya diri dalam pemecahan masalah.

Tapi pada kenyataannya masih banyak siswa yang beranggapan bahwa matematika itu sulit karena selalu berhubungan dengan angka, rumus dan hitung-menghitung. Pemikiran awal seseorang yang seperti itu jelas akan memengaruhi terhadap penguasaan matematika seseorang karena sebelumnya sudah ada rasa takut tidak bisa memahami pelajaran matematika dan malas. Mereka sudah terlebih dahulu tidak tertarik dengan matematika sebelum mencobanya.Salah satunya yaitu dalam menyelesaikan soal matematika bentuk cerita.Soal cerita disajikan dalam bentuk cerita dan masalah yang diungkapkan merupakan masalah kehidupan sehari-hari.

Kebanyakan siswa merasa kesulitan dalam memahami maksud dari soal yang diberikan, apa 
yang ditanyakan dalam soal tersebut, dan masih banyak pula terdapat kesalahan dalam perhitungan. Hal itu dikarenakan dalam menyelesaikan soal matematika dalam bentuk cerita diperlukan langkahlangkah pemahaman dan daya nalar yang tinggi.Masih banyak siswa yang kurang memahami bagaimana menterjemahkan kalimat sehari-hari soal ke dalam kalimat matematika atau model matematika.

Pranoto (2012) Siklus pengajaran mata pelajaran matematika di sekolah, hampir mengikuti pakem yang sama seperti guru masuk kelas, menyapa, lalu menuliskan rumus pada papan tulis, kemudian memberikan contoh pengerjaannya, dan akhirnya meminta siswa mengerjakan kumpulan soal-soal latihan.Pengajaran matematika yang dogmatis seperti itu membuat siswa menganggap matematika itu sulit. Jika metode pengajaran yang dilakukan oleh guru seperti itu, maka itu bukanlah matematika tetapi matematika semu.Padahal, kecakapan yang diperlukan oleh siswa bukan menghapal melainkan kemampuan untuk menyelesaikan masalah dan berkomunikasi.

Mc Shane dan Glinow dalam Buyung (2007)kemampuan adalah kecerdasan-kecerdasan alami dan kapabilitas dipelajari yang diperlukan untuk menyelesaikan suatu tugas.Dengan demikian, kemampuan siswa dalam menyelesaikan soal matematika dalam bentuk cerita meliputi beberapa langkah penyelesaian yaitu kemampuan memahami soal, membuat model matematika, dan perhitungan. Jika salah satu langkah penyelesaian terdapat kesalahan, maka akan menyebabkan kesalahan pada langkah selanjutnya dan mengakibatkan rendahnya hasil yang diperoleh siswa dalam menyelesaikan soal matematika dalam bentuk cerita.

Pada dasarnya setiap penyelesaian soal matematika memerlukan kemampuan penalaran.Melalui penalaran, siswa diharapkan dapat melihat bahwa matematika merupakan kajian yang masuk akal dan logis.Dengan demikian siswa merasa yakin bahwa matematika dapat dipahami, dipikirkan, dibuktikan, dan dapat dievaluasi.Dan untuk mengerjakan hal-hal yang berhubungan diperlukan bernalar.

Lithner dalam Rosita (2010) penalaran adalah pemikiran yang diadopsi untuk menghasilkan pernyataan dan mencapai kesimpulan pada pemecahan masalah yang tidak selalu didasarkan pada logika formal sehingga tidak terbatas pada bukti.
Suherman dan Winataputra (1993) penalaran adalah proses berpikir yang dilakukan dengan suatu cara untuk menarik kesimpulan. Kesimpulan yang diperoleh dari hasil bernalar, didasarkan pada pengamatan datadata yang ada sebelumnya dan telah diuji kebenarannya. Hal ini sejalan dengan pendapat Shadiq dalam sumartini (2015) yang mengemukakan bahwa penalaran adalah suatu proses atau suatu aktifitas berpikir untuk menarik suatu kesimpulan atau membuat suatu pernyataan baru yang benar berdasar pada beberapa pernyataan yang kebenarannya telah dibuktikan atau diasumsikan sebelumnya.

Dari beberapa definisi penalaran yang dipaparkan oleh para ahli diatas, ternyata mengarah pada suatu pengertian yaitu penalaran sebagai suatu aktivitas atau proses penarikan kesimpulan yang ditandai dengan adanya langkah-langkah proses berpikir.

Soemarmo (2014) secara garis besar penalaran matematis (mathematical reasoning) diklasifikasi dalam dua jenis yaitu penalaran induktif dan penalaran deduktif.Secara umum penalaran induktif didefinisikan sebagai penarikan kesimpulan berdasarkan terhadap data terbatas.Karena berdasarkan keterbatasan banyaknya pengamatan tersebut, maka nilai kebenaran kesimpulan dalam penalaran induktif tidak mutlak tetapi bersifat probabilistik. Ditinjau dari karakteristik proses penarikan kesimpulannya, penalaran induktif meliputi beberapa kegiatan sebagai berikut:

1. Penalaran transduktif yaitu proses menarik kesimpulan dari pengamatan terbatas dan diberlakukan terhadap kasus tertentu

2. Penalaran analogi yaitu proses menarik kesimpulan berdasarkan keserupaan proses atau data

3. Penalaran generalisasi yaitu proses menarik kesimpulan secara umum berdasarkan data terbatas

4. Memperkirakan jawaban, solusi atau kecenderungan: interpolasi dan ekstrapolasi

5. Memberi penjelasan terhadap model, fakta, sifat, hubungan atau pola yang ada

6. Menggunakan pola hubungan untuk menganalisis situasi, dan menyusun konjektur.

Penalaran deduktif adalah penarikan kesimpulan berdasarkan aturan yang disepakati. Bani (2011) penalaran deduktif merupakan proses berpikir 
untuk menarik kesimpulan tentang hal khusus yang berpijak pada hal umum atau hal yang sebelumnya telah dibuktikan/diasumsikan kebenarannya. Ramdani (2012) penalaran deduktif adalah proses penalaran dari pengetahuan prinsip atau pengalaman yang umum yang menuntun kita memperoleh kesimpulan untuk sesuatu yang khusus. Berdasarkan pendapat para ahli dapat disimpulkan bahwa penalaran deduktif matematis adalah penalaran yang bekerja atas dasar asumsi, yaitu kebenaran suatu konsep atau pernyataan diperoleh sebagai akibat logis dari kebenaran sebelumnya. Beberapa kegiatan yang tergolong pada penalaran deduktif diantaranya adalah:

1. Melaksanakan perhitungan berdasarkan aturan atau rumus tertentu.

2. Menarik kesimpulan logis (penalaran logis): berdasarkan aturan inferensi, berdasarkan proporsi yang sesuai, berdasarkan peluang, korelasi antara dua variabel, menetapkan kombinasi beberapa variabel.

3. Menyusun pembuktian langsung, pembuktian tak langsung dan pembuktian dengan induksi matematika.

4. Menyusun analisis dan sintesis beberapa kasus.

5. Kemampuan pada butir a secara konseptual pada umumnya tergolong berpikir matematis prosedural dan melaksanakan perhitungan rutin, namun demikian perhitungan tertentu melibatkan bilangan yang sukar. Sebagai contoh perhitungan integral bagian pada dasarnya merupakan proses yang procedural, namun dalam hal fungsi yang diintegralkan tidak sederhana maka perhitugannya menjadi rumit.

Sumarmo (2014) indikator kemampuan penalaran deduktif matematis dalam pembelajaran matematika adalah sebagai berikut: menarik kesimpulan logis, memberikan penjelasan dengan model, fakta, sifat-sifat, dan hubungan, memperkirakan jawaban dan proses solusi, menggunakan pola dan hubungan untuk menganalisis situasi matematis, menyusun dan mengkaji konjektur, merumuskan lawan mengikuti aturan inferensi, memeriksa vaiditas argument, menyusun argumen yang valid, menyusun pembuktian langsung, tak langsung, dan menggunakan induksi matematis. Namun dalam alam penelitian ini, indikator yang digunakan yaitu 3 indikator yaitu:

1. Melaksanakan perhitungan berdasarkan aturan atau rumus tertentu

2. Menarik kesimpulan logis (penalaran logis)

3. Menyusun pembuktian langsung, pembuktian tak langsung dan pembuktian dengan induksi matematika.

Berdasarkan latar belakang masalah di atas, perumusan masalah dalam penelitan adalah ini:

1. Bagaimana tingkat kemampuan penalaran deduktif matematis siswa dalam menyelesaikan soal matematika bentuk cerita pokok bahasan aplikasi turunan?.

2. Berapa tingkat persentase penalaran deduktif matematis yang dilakukan siswa dalam menyelesaikan soal matematika bentuk cerita pokok bahasan aplikasi turunan?.

\section{B. METODE PENELITIAN}

Penelitian ini dilaksanakan di SMA Muhammadiyah 02 Cipondoh Tangerang, waktu penelitian dilaksanakan pada bulan November 2018 sampai dengan Maret 2019.Jenis metode penelitian yang digunakan adalah penelitian kualitatif deskriptif karena penelitian ini bertujuan untuk memperoleh gambaran secara empirik tentang kemampuan penalaran deduktif matematis siswa SMA MuhammadiyahCipondoh Tangerang dalam menyelesaikan soal cerita pokok bahasan aplikasi turunan. Kahija (2006) penelitian kualitatif sebagai proses mendeskripsikan dan memahami dunia pengalaman subyek/partisipan dengan berpangkal pada tradisi-tradisi dan rancangan-rancangan penelitian kualitatif tertentu. Mukhtar (2013) yang mengartikan penelitian kualitatif deskriptif sebagai suatu metode yang digunakan untuk menemukan pengetahuan terhadap subyek penelitian pada suatu saat tertentu.

Metode penelitian deskriptif digunakan untuk memecahkan masalah yang dihadapi pada masa sekarang dan dapat dilakukan dengan menempuh langkah-langkah pengumpulan data, klasifikasi dan analisis/laporan dengan tujuan utama membuat penggambaran tentang keadaan secara objektif dalam suatu deskripsi situasi.Prosedur penelitian yang digunakan peneliti terdiri dari tiga tahap yaitu tahap pelaksanaan, tahap analisis data dan pembuatan laporan. 
1. Tahap perencanaan:menyusun instrumen tes kemampuan penalaran deduktif matematis berdasarkan indikator kemampuan penalaran deduktif dan pedoman wawancara, melakukan uji coba instrumen tes, dan melakukan validitas dan reliabilitas terhadap instrumen tes.

2. Tahap pelaksanaan: melakukan tes kemampuan penalaran deduktif matematis siswa kelas XI IPA 2 yang berjumlah 39 siswa yang merupakan objek penelitian, menganalisis hasil tes kemampuan penalaran deduktif, memilih subyek penelitian berdasarkan hasil tes kemampuan penalaran deduktif matematis. Berdasarkan hasil nilai tersebut, siswa dikelompokkan ke dalam 3 ranking.

3. Tahap analisis data: melakukan analisis data yang telah didapatkan pada tahap pelaksanaan (hasil tes dan wawancara), dan menarik kesimpulan dan verifikasi.

Sumber data dalam penelitian kualitatif terbagi menjadi dua macam, yaitu data primer dan data sekunder.Data primer yang akan digunakan pada saat penelitian adalah pedoman atau catatan wawancara yang didapat dari hasil wawancara oleh guru. Data sekunder yang akan digunakan pada saat penelitian adalah foto-foto dan data statistik, data ini berguna untuk tambahan pendukug dari data primer setelah dilakukannya wawancara atau observasi.

Untuk memperoleh data sesuai dengan tujuan yang diharapkan, maka dalam penelitian ini menggunakan beberapa teknik pengumpulan data, yaitu: Observasi: Hal-hal yang di observasi dalam penelitian ini yaitu kemampuan penalaran deduktif matematis siswa dalam menyelesaiakan soal cerita pokok bahasan baris dan deret. Tes: Tes yang akan digunakan untuk penelitian adalah tes berbentuk uraian. Tujuannya diberikan tes tersebut untuk mendeskripsikan dan menganalisis kemampuan penalaran matematis siswa pada pokok bahasan baris dan deret. Wawancara:Wawancara yang digunakan adalah wawancara tidak terstruktur artinya wawancara yang bebas dimana peneliti menggunakan pedoman wawancara yang telah tersusun secara sistematis dan lengkap untuk pengumpulan datanya atau tidak menggunakan pedoman wawancara. Pedoman wawancara yang digunakan hanya berupa garis-garis besar permasalahan yang akan ditanyakan.
Instrumen yang digunakan dalam penelitian ini berupa tes kemampuan penalaran deduktif matematis siswa kelas XI IPA 2 setelah itu melakukan wawancara kepada siswa berdasarkan pedoman wawancara yang sesuai dengan indikator kemampuan penalaran deduktif matematis. Teknik analisis data yang digunakan dalam penelitian ini adalah:

1. Memberikan Skor: Sumarmo (2014) Skor yang diperoleh siswa merupakan hasil tes yang dapat mendeskripsikan atau menggambarkan kemampuan penalaran matematis.

Tabel 1. Pedoman Penskoran Tes Kemampuan Penalaran Matematis

\begin{tabular}{|c|c|c|c|}
\hline \multirow[b]{2}{*}{ Skor } & \multicolumn{3}{|c|}{ Indikator } \\
\hline & $\begin{array}{c}\text { Melakukan } \\
\text { perhitungan } \\
\text { dengan rumus }\end{array}$ & $\begin{array}{c}\text { Penalaran } \\
\text { logis }\end{array}$ & $\begin{array}{c}\text { Menyusun } \\
\text { pembuktian } \\
\text { langsung } \\
\end{array}$ \\
\hline 0 & \multicolumn{3}{|c|}{ Tidak ada jawaban } \\
\hline 1 & $\begin{array}{l}\text { Mengidentifikasi } \\
\text { proses/konsep } \\
\text { matematika } \\
\text { pada } \\
\text { situasi/masalah } \\
\text { yang diberikan, } \\
\text { ditanyakan } \\
\text { serta memeriksa } \\
\text { kecukupan } \\
\text { unsur }\end{array}$ & $\begin{array}{l}\text { Memhami } \\
\text { informasi } \\
\text { pada soal } \\
\text { yang } \\
\text { diberikan. }\end{array}$ & $\begin{array}{l}\text { Menyatakan } \\
\text { data/unsur } \\
\text { yang } \\
\text { diketahui dan } \\
\text { pernyataan } \\
\text { yang akan } \\
\text { dibuktikan }\end{array}$ \\
\hline 2 & $\begin{array}{l}\text { Mengidentifikasi } \\
\text { proses/konsep } \\
\text { matematika } \\
\text { pada } \\
\text { situasi/masalah } \\
\text { yang diberikan, } \\
\text { ditanyakan } \\
\text { serta memeriksa } \\
\text { kecukupan } \\
\text { unsur, } \\
\text { menyusun } \\
\text { model } \\
\text { matematika } \\
\text { masalah, } \\
\text { menyelesaikan } \\
\text { model } \\
\text { matematika } \\
\text { masalah } \\
\text { masalah tanpa } \\
\text { disertai alasan } \\
\text { atau } \\
\text { menyertakan } \\
\text { proses/konsep/ } \\
\text { aturan } \\
\text { matematika } \\
\text { yang digunakan. }\end{array}$ & $\begin{array}{l}\text { Memhami } \\
\text { informasi } \\
\text { pada soal } \\
\text { yang } \\
\text { diberikan } \\
\text { tanpa } \\
\text { menjelaska } \\
\text { n langkah- } \\
\text { langkah } \\
\text { pemecahan } \\
\text { masalah } \\
\text { tersebut, } \\
\text { kemudian } \\
\text { menyelesai } \\
\text { kan } \\
\text { permasalah } \\
\text { an tetapi } \\
\text { tidak runtut } \\
\text { dan } \\
\text { menetapka } \\
\text { n kesimpulan }\end{array}$ & $\begin{array}{l}\text { Menyatakan } \\
\text { data/unsur } \\
\text { yang } \\
\text { diketahui dan } \\
\text { pernyataan } \\
\text { kemudian } \\
\text { menyusun } \\
\text { model } \\
\text { matematika } \\
\text { masalah dan } \\
\text { pernyataan } \\
\text { yang akan } \\
\text { dibuktikan. }\end{array}$ \\
\hline 3 & $\begin{array}{l}\text { Mengidentifikasi } \\
\text { proses/konsep } \\
\text { matematika } \\
\text { pada }\end{array}$ & $\begin{array}{l}\text { Memhami } \\
\text { informasi } \\
\text { pada soal } \\
\text { yang }\end{array}$ & $\begin{array}{l}\text { Menyatakan } \\
\text { data/unsur } \\
\text { yang } \\
\text { diketahui dan }\end{array}$ \\
\hline
\end{tabular}




\begin{tabular}{|c|c|c|c|}
\hline & $\begin{array}{l}\text { situasi/masalah } \\
\text { yang diberikan, } \\
\text { ditanyakan } \\
\text { serta memeriksa } \\
\text { kecukupan } \\
\text { unsur, } \\
\text { menyusun } \\
\text { model } \\
\text { matematika } \\
\text { masalah, } \\
\text { menyelesaikan } \\
\text { model } \\
\text { matematika } \\
\text { masalah } \\
\text { masalah disertai } \\
\text { alasan atau } \\
\text { menyertakan } \\
\text { proses/konsep/ } \\
\text { aturan } \\
\text { matematika } \\
\text { yang digunakan. }\end{array}$ & $\begin{array}{l}\text { diberikan } \\
\text { tanpa } \\
\text { menjelaska } \\
\mathrm{n} \text { langkah- } \\
\text { langkah } \\
\text { pemecahan } \\
\text { masalah } \\
\text { tersebut, } \\
\text { kemudian } \\
\text { menyelesai } \\
\text { kan } \\
\text { permasalah } \\
\text { an dengan } \\
\text { runtut dan } \\
\text { menetapka } \\
\mathrm{n} \\
\text { kesimpulan }\end{array}$ & $\begin{array}{l}\text { pernyataan } \\
\text { yang akan } \\
\text { dibuktikan, } \\
\text { menyusun } \\
\text { model } \\
\text { matematika } \\
\text { masalah dan } \\
\text { pernyataan } \\
\text { yang akan } \\
\text { dibuktikan, } \\
\text { melaksanaka } \\
\text { n proses- } \\
\text { proses } \\
\text { matematika } \\
\text { yang danga } \\
\text { relevantanpa } \\
\text { disertai } \\
\text { dengan } \\
\text { penjelasan } \\
\text { dan tan bukti } \\
\text { menyatakan } \\
\text { kembali buk } \\
\text { ke dalam } \\
\text { bentuk } \\
\text { kalimat biasa. }\end{array}$ \\
\hline 4 & $\begin{array}{l}\text { Mengidentifikasi } \\
\text { proses/konsep } \\
\text { matematika } \\
\text { pada } \\
\text { situasi/masalah } \\
\text { yang diberikan, } \\
\text { ditanyakan } \\
\text { serta memeriksa } \\
\text { kecukupan } \\
\text { unsur, } \\
\text { menyusun } \\
\text { model } \\
\text { matematika } \\
\text { masalah, } \\
\text { menyelesaikan } \\
\text { model } \\
\text { matematika } \\
\text { masalah } \\
\text { masalah disertai } \\
\text { alasan atau } \\
\text { menyertakan } \\
\text { proses/konsep/ } \\
\text { aturan } \\
\text { matematika } \\
\text { yang digunakan. }\end{array}$ & $\begin{array}{l}\text { Memhami } \\
\text { informasi } \\
\text { pada soal } \\
\text { yang } \\
\text { diberikan } \\
\text { dengan } \\
\text { menjelaska } \\
\mathrm{n} \text { langkah- } \\
\text { langkah } \\
\text { pemecahan } \\
\text { masalah } \\
\text { tersebut, } \\
\text { kemudian } \\
\text { menyelesai } \\
\text { kan } \\
\text { permasalah } \\
\text { an dengan } \\
\text { runtut dan } \\
\text { menetapka } \\
\mathrm{n} \\
\text { kesimpulan }\end{array}$ & $\begin{array}{l}\text { Menyatakan } \\
\text { data/19 nsure } \\
\text { yang } \\
\text { diketahui dan } \\
\text { pernyataan } \\
\text { yang akan } \\
\text { dibuktikan, } \\
\text { mnyusun } \\
\text { model } \\
\text { matematika } \\
\text { masalah dan } \\
\text { pernyataan } \\
\text { yang akan } \\
\text { dibuktikan, } \\
\text { melaksanaka } \\
\text { n proses- } \\
\text { proses } \\
\text { matematika } \\
\text { yang relevan } \\
\text { disertai } \\
\text { dengan } \\
\text { penjelasan, } \\
\text { menyatakan } \\
\text { kembali bukti } \\
\text { kedalam } \\
\text { bentuk } \\
\text { kalimat biasa. }\end{array}$ \\
\hline
\end{tabular}

2. Reduksi Data: Berikut langkah-langkah reduksi data dalam penelitian adalah:

a. Memeriksa hasil tes kemampuan penalaran deduktif matematis siswa.

b. Hasil tes kemampuan penalaran deduktif matematis dikerjakan siswa berupa data akan dijadikan catatan untuk wawancara dengan siswa. c. Hasil wawancara dengan siswa yang sudah dilaksanakan disusun dengan menggunakan bahasa yang baik selanjutnya dimasukkan kedalam catatan.

3. Penyajian Data: penyajian data hasil tes kemampuan penalaran deduktif matematis siswa dan penyajian data hasil wawancara dengan siswa kemudian hasil tersebut akan dianalisis oleh peneliti.

4. Menarik Kesimpulan/Verifikasi: Penarikan kesimpulan dalam penelitian kualitatif adalah merupakan temuan baru yang sebelumnya belum pernah ada (Sugiyono, 2011). Penarikan kesimpulan adalah tahap analisis data yang telah disajikan dalam bentuk tabel. Untuk mengetahui persentase penalaran deduktif yang dilakukan siswa dalam menyelesaikan soal matematika bentuk cerita pokok bahasan aplikasi turunan.

Subjektivitas peneliti merupakan hal yang dominan dalam penelitian kualitatif, mengingat dalam penelitian kualitatif, peneliti sebagai instrument penelitian, ditambah lagi teknik pengumpulan data utama penelitian kualitatif adalah wawancara dan observasi yang dianggap banyak kelemahan ketika dilakukan secara terbuka dan apalagi tanpa kontrol. Moleong (2005) menyatakan bahwa untuk menetapkan keabsahan data diperlukan teknik pemeriksaan atas empat krieria yaitu: derajat kepercayaan (Credibility), keteralihan (Transferbility), kebergantungan (Dependability), dan kepastian (Confirmability).

\section{HASIL DAN PEMBAHASAN}

Setelah melalui beberapa rangkaian tahapan pelaksanaan penelitian, didapatkan beberapa temuan-temuan, yaitu:

Tabel 2. Persentase Indikator Tiap Soal

\begin{tabular}{|c|c|c|c|}
\hline $\begin{array}{l}\text { No. } \\
\text { Soal }\end{array}$ & Indikator Soal & Frekuensi & Persentase \\
\hline 1 & \multirow{3}{*}{$\begin{array}{l}\text { Siswa dapat } \\
\text { melaksanakan } \\
\text { perhitungan } \\
\text { berdasarkan aturan } \\
\text { atau rumus tertentu }\end{array}$} & 79 & $50,64 \%$ \\
\hline 2 & & 73 & $46,79 \%$ \\
\hline 3 & & 111 & $71,15 \%$ \\
\hline 4 & \multirow{2}{*}{$\begin{array}{ll}\text { Siswa } & \text { dapat } \\
\text { menarik } & \\
\text { kesimpulan logis } & \\
\text { (penalaran logis) }\end{array}$} & 81 & $51,92 \%$ \\
\hline 5 & & 46 & $29,49 \%$ \\
\hline 6 & \multirow{2}{*}{$\begin{array}{ll}\text { Siswa dapat } \\
\text { menyusun }\end{array}$} & 96 & $61,54 \%$ \\
\hline 7 & & 118 & $75,64 \%$ \\
\hline
\end{tabular}




\begin{tabular}{clcc}
\hline 8 & $\begin{array}{l}\text { pembuktian } \\
\text { langsung }\end{array}$ & 108 & $69,23 \%$ \\
\hline & Tabel 3. Persentase Total Perindikator \\
\hline $\begin{array}{c}\text { No. } \\
\text { Soal }\end{array}$ & \multicolumn{1}{c}{ Indikator } & Frekuensi & Persentase \\
\hline & $\begin{array}{l}\text { Siswa dapat } \\
\text { melaksanakan } \\
\text { perhitungan } \\
\text { berdasarkan } \\
\text { aturan atau } \\
\text { rumus tertentu }\end{array}$ & & \\
\hline & $\begin{array}{l}\text { Siswa dapat } \\
\text { menarik } \\
\text { kesimpulan logis } \\
\text { penalaran logis) }\end{array}$ & & \\
\hline & $\begin{array}{l}\text { Siswa dapat } \\
\text { menyusun } \\
\text { pembuktian } \\
\text { langsung }\end{array}$ & & \\
\hline
\end{tabular}

Tabel 4. Kriteria Pengelompokan Berdasarkan Tes Penalaran Deduktif Matematis

\begin{tabular}{ccc}
\hline $\begin{array}{c}\text { Kriteria } \\
\text { Pengelompokkan }\end{array}$ & Interval & Kriteria \\
\hline Nilai $\geq$ Mean + SB & nilai $\geq 64,99$ & Tinggi \\
\hline $\begin{array}{c}\text { Mean }- \text { SB } \leq \text { Nilai }<\text { Mean } \\
+ \text { SB }\end{array}$ & $\begin{array}{c}49,17 \leq \text { nilai }< \\
64,99\end{array}$ & Sedang \\
\hline $\begin{array}{c}\text { Nilai } \geq \text { Mean + SB < Mean } \\
\text { - SB }\end{array}$ & nilai $<49,17$ & Rendah \\
\hline
\end{tabular}

Berdasarkan analisis data dari hasil penelitian yang diperoleh dari pekerjaan siswa dan data wawancara maka siswa yang memiliki kemampuan penalaran deduktif matematis tinggi yaitu sisa yang memenuhi hampir seluruh indikator kemampuan penalaran deduktif matematis yakni:

1. melaksanakan perhitungan berdasarkan aturan atau rumus tertentu

2. menarik kesimpulan logis (penalaran logis)

3. menyusun pembuktian langsung.

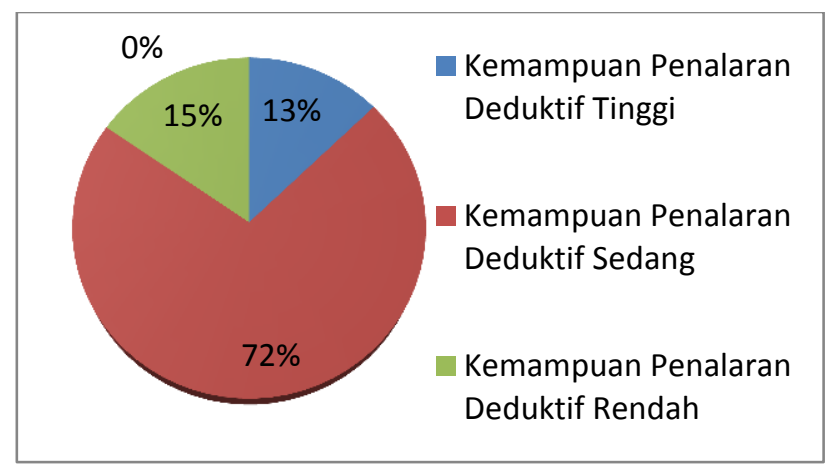

Gambar1.Persentase Total Kemampuan Penalaran Deduktif Matematis

\section{SIMPULAN DAN SARAN}

Berdasarkan hasil penelitian tentang analisis kemampuan penalaran deduktis matematis siswa pada pokok bahasan aplikasi turunan diperoleh beberapa kesimpulan yakni (1) Tingkat persentase berdasarkan tingkat kemampuan penalaran deduktif matematis untuk kemampuan penalaran deduktif tinggi sekitar 12,82\% sedangkan kemampuan penalaran deduktif sedang mencapai $71,8 \%$ dan kemampuan penalaran deduktif rendah mencapai $15,38 \%$; (2) Faktor - faktor yang menyebabkan kurangnya kemampuan penalaran deduktif matematis pada materi aplikasi turunan yaitu (a) Siswa tidak menguasai atau memahami dengan benar konsep yang digunakan dalam menyelesaikan soal soal yang dikerjakan; (b) Malu bertanya ketika siswa kurang memahami materi yang diberikan atau tidak fokus dalam belajar; (c) Siswa kurang percaya diri dalam menjawab soal yang diberikan; dan (d) Siswa kurang melatih diri mengerjakan soal-soal latihan untuk memperdalam dan memperluas materi pembelajaran sekaligus mengulang kembali materi yang diajarkan.

Berdasarkan simpulan tersebut, maka tim peneliti memberikan beberapa sarab yakni (1) Pada materi aplikasi turunan sebaiknya guru terlebih dahulu mengajarkan siswa konsep dalam menyelesaikan soal turunan; (2) Setiap akhir pertemuan, sebaiknya guru melakukan evaluasi terhadap pembelajaran yang telah dilaksanakan. Hal ini bertujuan untuk memperbaiki kualitas pembelajaran selanjutnya, sehingga tujuan pembelajaran yang diinginkan tercapai; dan (3) Siswa kurang terbiasa dengan soal-soal yang tidak rutin. Oleh karena itu, guru hendaknya membiasakan pemberian soal yang tidak rutin kepada siswa.

\section{UCAPAN TERIMA KASIH}

Ucapan terima kasih yang sebesar-besarnya kepada semua pihak yang telah membantu dan terlibat dalam proses penelitian terutama kepada pihak SMA Muhammadiyah 02 Cipondoh Tangerang yang telah memberikan waktu dan tempat, dan kepada para pakar yang telah bersedia memvalidassi dan merevisi instrumen. 


\section{REFERENSI}

Bani, A. (2011). Meningkatkan Kemampuan Pemahaman dan penalaran Matematika Siswa Sekolah Menengah Pertama Melalui Penemuan Terbimbing, Edisi Khusus No.1 Agustus 2011, 12-20

Buyung, Kusumawati I, and Ressy, N. (2016). Pengaruh Strategi Pembelajaran Inkuiri (SPI) Terhadap Kemampuan Pemahaman Konsep Siswa Kelas VIII SMP Negeri 18 Singkawang Selatan. Jurnal Pendidikan Matematika Indonesia, 1(2), 87-90

Depdiknas. (2006). Standar Isi. Jakarta: Depdiknas

Hendriana, Heris \& Soemarmo, Utari. (2014). Penilaian Pembelajaran Matematika. Bandung: PT Refika Aditama.

La Kahija, Y. F. (2006). Pengenalan \& penyusunan proposal/skripsi penelitian fenomenologis. Semarang: Fakultas Psikologi Universitas Diponegoro.

Mukhtar (2013). Metode Penelitian Deskriptif Kualitatif. Jakarta : GP Press Group

Pranoto, I (2013). Kasmaran Bermatematika. Jakarta: Harian Kompas

Ramdani, Yani (2012). Pengembangan Instrumen dan Bahan Ajar untuk Meningkatkan Kemampuan Komunikasi, Penalaran, dan Koneksi Matematis dalam Konsep Integral. Jurnal Penelitian Pendidikan,13(1), 44-52

Rosita. C. D (2010). Kemampuan Penalaran dan Komunikasi matematis: Apa, Mengapa, dan bagaimana ditingkatkan pada mahasiswa. Euclid, 1(1), 33-46

Suherman,E\& Winataputra, U.S. (1993). Strategi Belajar Mengajar Matematika. Jakarta: Universitas Terbuka.

Sugiyono (2011). Metode Penelitian Kuantitatif Kualitatif dan R\&D. Bandung: Alfabeta

Sumartini, T. S (2015). Peningkatan kemampuan Penalaran matematis siswa melalui pembelajaran berbasis masalah. MOSHARAFA: Jurnal Pendidikan Matematika, 5(1),1-10 